\title{
The Role of C Reactive Protein in Fever without Focus among Children Aged Between 1 - 3 Years
}

\author{
Dhipu Mathew', Deepa Mathew ${ }^{2}$ \\ ${ }^{1}$ Assistant Professor, Department of Respiratory Medicine, Mount Zion Medical College, Chayalode, adoor, ${ }^{2}$ Assistant Professor, Department of Pediatrics, \\ Aurupadai Vinayaka Mission Medical College, Pondicherry.
}

\section{Abstract}

Background: The incidence of invasive pneumococcal disease in children has come down because of polysaccharide vaccine. The increased incidence of bacteremia among young children may be due to part of maturational immune deficiency in the production of opsonic Ig Ganti bodies to the polysaccharide antigens present on en capsulated bacteria. Fever is a common present in gsymp to min paediatric out patient practice and in children less 3 years of age. Approximately $20 \%$ to $30 \%$ of the children may have no identifiable cause off ever after history and physical examination. Subjects and Methods: Children in the age group of 1-3 years presenting to the outpatient department were screened for temperature $>39^{\circ} \mathrm{C}$ and who satisfied inclusion criteria were included in the study. Temperatures were recorded either in the axillary or rectal areas. Informed consent was obtained from parents or guardian \& clearance of Institutional Ethical Committee Review Board. Blood samples were taken for total WBC count, ANC, ESR and CRP and at the same time samples for blood culture. Blood cultured in various media incubated overnight and colony morphology was read. Results: CRP $>6 \mathrm{mg} / \mathrm{d} 1$ was observed in 25 cases of children who had SBI giving rise to sensitivity of $75.8 \%, 46$ children who did not have SBI have CRP <6mg/d1 giving a specificity of $39.3 \%$. Among 96 cases with CRP more than $6 \mathrm{mg} / \mathrm{d} 1$ only 25 (26\%) cases had SBI giving PPV of 26\%. Among 54 cases of CRP <6mg/d1 46(85\%) cases did not have SBI giving a NPV of $85.2 \%$. Conclusion: CRP determines more selective strategy for children with SBI for additional diagnostic studies and appropriate antibiotic therapy.

Keywords: C reactive Protein, Fever, Children.

Corresponding Author: Dr. Deepa Mathew, Assistant Professor, Department of Pediatrics, Aurupadai Vinayaka Mission Medical College, Pondicherry.

Received: October 2019

Accepted: October2019

\section{Introduction}

Fever without localizing sign sorsymptoms, usually of acute on set and present for less than one week. It is more common in children less than 36 months of age. Children with fever in whom cause could not be identified after 3 week of evaluation asan out patient or after 1 week of evaluation in hospital. ${ }^{[1]}$

Fever is a common manifestation of infectious diseases but is not predictive of severity. Many common viral and bacterial infections are-usually benign in normal hosts and respond well to appropriate anti microbial or supportive therapy. Other infections such assepsis, meningitis, pneumonia, osteoarticular infections, pyelonephritis, ifuntreated, may have significant morbidity ormortality. They are considered to be serious bacterial infections.

Most febrile episodes in a normal host can be diagnosed by a careful history and physical examination and require few if any laboratory tests. Febrile patients at increased risk for serious bacterial infections are neonates, infants less than three months children between 3 months to 36 months, children with hyperpyrexia 3 and immunecompromised patients. Approximately $30 \%$ off ebrile children between 1 yr to 3 years have no localizing sign sofinfection. ${ }^{[2]}$

The incidence of invasive pneumococcal disease in children has come down because of polysaccharide vaccine. The increased incidence of bacteremia among young children may be dueto part of maturational immune deficiency in the production of opsonic Ig Ganti bodies to the poly saccharide antigens present on encapsulated bacteria. ${ }^{[3]}$

Fever is a common presenting symptom min paediatric out patient practice and in children less 3 years of age. Approximately $20 \%$ to $30 \%$ of the children may have no identifiable cause off ever after history and physical examination.

Although most of these children will have a benign viral illness. Children less than 3 years of age area increased risk of clinically undetectableerious bacterial infection (SBI). The incidence of serious bacterial infection is roughly about $10-15 \%$ ofpreviously healthy children presenting with rectal temperature more than $39^{\circ} \mathrm{C}$. Approximately2- 


\section{Years}

$3 \%$ of these children have Occult Bacteremia(OB) 2-8\% have UTI depending on the age and gender. Other causes of serious bacterial infection include occult bacterial pneumoniain $3 \%$ of children less than $3 \mathrm{yrs}, 5 \%$ will have other infections such as bone and joint infection, meningitis, soft tissue infection or bacterial enteritis. Although anti biotictreatment is necessary for children with serious bacterial infection it is also important to limit therapy in those children at greatest risk. ${ }^{[4]}$

Common etiological agents in less than 3 yrs: Group B Streptococci and List eriamonocytogens, Salmonella, E.coli, Neisseria etc. Fever is a controlled increase in body temperature over the normal values for an individual. Body temperature is regulated bythermo-sensitive neurons located in the pre opticoranteri or hypothalamus that respond to changes in blood temperature as well as to directneural connections with cold and warmreceptors located in sk in and muscle. ${ }^{[5]}$

Thermoregulatory responses include ere directing blood to or from cutaneous vascular beds, increased or decreased sweating, extra cellular fluid volume regulation(via Argininevaso press in) and behavioral responses, such as seeking awarmeror cooler environmental

temperature. Normal body temperature also varies in a regular pattern each day. This circadian temperature rhythm, or diurnal variation, results in lowerbody temperature in early morning and temperatures approximately higher in the late afternoon and early evening. ${ }^{[6]}$

\section{Subjects and Methods}

Study Design: Descriptive Study Evaluation of a Diagnostic Test

Study Population: lyr to $3 \mathrm{yrs}$

Sample Size: 150 .

Inclusion Criteria:

- Children aged 1 yr to 3 yrs

- Fever more than 12 hours up to 7 days 1

- Without obvious focus of infection on clinical examination.

- Exclusion Criteria

- Children who have received prior antibiotics and vaccines.

- Children with underlying immunological disease.

\section{Manoeuvre}

Children in the age group of 1-3 years presenting to the outpatient department were screened for temperature $>39^{\circ} \mathrm{C}$ and who satisfied inclusion criteria were included in the study. Temperatures were recorded either in the axillary or rectal areas. Informed consent was obtained from parents or guardian \& clearance of Institutional Ethical Committee Review Board. Blood samples were taken for total WBC count, ANC, ESR and CRP and at the same time samples for blood culture. Blood cultured in various media incubated overnight and colony morphology was read. Urine analysis, urine culture, colony count, chest radiograph were done. CSF analysis was done for selected cases. Patients were reviewed thereafter. CRP was done by slide agglutination method. Qualitative CRP followed by Semiquantitative CRP was performed. CRP-Agglutination in highest serum dilution corresponds to amount of CRP in $\mathrm{mg} / \mathrm{dl}$. The findings were recorded in a prescribed data entry form (Annexure). CRP Estimation: It is based on the principle of agglutination. One drop of test specimen is placed on a slide after centrifugation using a disposable pipette to which a drop of CRP reagent is added. Both test specimen and the reagent to be uniformly mixed over the entire circle, using a mixing stick.

\section{Results}

CRP $>6 \mathrm{mg} / \mathrm{d} 1$ was observed in 25 cases of children who had SBI giving rise to sensitivity of $75.8 \%, 46$ children who did not have SBI have CRP $<6 \mathrm{mg} / \mathrm{d} 1$ giving a specificity of $39.3 \%$. Among 96 cases with CRP more than $6 \mathrm{mg} / \mathrm{d} 1$ only $25(26 \%)$ cases had SBI giving PPV of 26\%. Among 54 cases of CRP $<6 \mathrm{mg} / \mathrm{d} 146(85 \%)$ cases did not have SBI giving a NPV of $85.2 \%$.

Table 1: Comparison of characteristics of CRP positive and negative

\begin{tabular}{|l|l|l|l|l|}
\hline \multirow{2}{*}{$\begin{array}{c}\text { Duration of } \\
\text { fever }\end{array}$} & \multicolumn{3}{|c|}{ CRP } & \multirow{2}{*}{ P-value } \\
\cline { 2 - 4 } & Total & \multicolumn{1}{|c|}{$\begin{array}{c}\text { Positive } \\
(\%)\end{array}$} & $\begin{array}{c}\text { Negative } \\
(\%)\end{array}$ & \\
\hline$<24$ Hours & 21 & 9 & 12 & 0.0614 \\
\hline $24-72$ Hours & 115 & 76 & 39 & \\
\hline$>72$ Hours & 14 & 11 & 3 & \\
\hline Total & 150 & 96 & 54 & \\
\hline
\end{tabular}

When fever was more 24 hours duration CRP was positive in $87(90.67 \%)$ cases when compared to 42 cases $(77.7 \%)$ across CRP negative. However duration of fever is insignificant. $p$ value is 0.0614

Table 1(ii): Comparison of characteristics of CRP positive and negative

\begin{tabular}{|l|l|l|l|l|}
\hline \multirow{2}{*}{ Age Group } & \multicolumn{3}{|c|}{ CRP } & \multirow{2}{*}{ P } \\
\cline { 2 - 4 } & Tolalue \\
\hline 1-2 years & $\begin{array}{c}\text { Positive } \\
(\%)\end{array}$ & $\begin{array}{c}\text { Negative } \\
(\%)\end{array}$ & \\
\hline 2-3 years & 61 & 37 & 24 & 0.4799 \\
\hline Total & 89 & 59 & 30 & \\
\hline
\end{tabular}

Among age more than 24 months 59 (61.5\%) cases were CRP positive, when compared to $30(55.5 \%)$ across CRP negative. $p$ value is insignificant. (0.4799).

ROC for variables associated with SBI. Area under the curve for CRP 0.575 (95\% CI: $0.468,0.682$ ); for ESR 0.555 (95\% CI: 0.457, 0.660); for ANC 0.689 (95\% CI: 0.581,0.796); and for WBC 0.911 (95\% CI: 0.859, 0.962).

\begin{tabular}{l}
\hline Table 2: Predictors of SBI (based on ROC curve) \\
\begin{tabular}{|l|l|l|l|l|l|l|}
\hline & $\begin{array}{l}\text { CUTOF } \\
\text { F }\end{array}$ & $\begin{array}{l}\text { Sensiti } \\
\text { ve }\end{array}$ & $\begin{array}{l}\text { Specifici } \\
\text { ty }\end{array}$ & $\begin{array}{l}\text { P red } \\
\text { Value } \\
\text { Positi } \\
\text { ve }\end{array}$ & $\begin{array}{l}\text { P red } \\
\text { value } \\
\text { Negati } \\
\text { ve }\end{array}$ & $\begin{array}{l}\text { Likeliho } \\
\text { od Ratio }\end{array}$ \\
\hline WB & 13.4 & 81.8 & 82.1 & 56.3 & 94.1 & 45.6 \\
C & & $(68.7$, & $(75.1,89)$ & $(42.2$, & $(89.6,98$ & $(30,69.3)$ \\
& & $95)$ & & $70.3)$ & $7)$ & \\
\hline AN & 19.3 & 63.8 & 97.1 & 90.9 & 85.5 & 219.1 \\
C & & $(50.1$, & $(93.8$, & $(81.1$, & $(79.1$, & $(70.4$, \\
& & $77.6)$ & $100.3)$ & $100.7)$ & $91.9)$ & $682.2)$ \\
\hline ECR & 17.1 & 54.5 & 55.6 & 25.7 & 81.3 & 12.3 \\
& & $(37.6$, & $(46.6,64.6)$ & 15.5, & $(72.7$, & $(8.5,17.8)$ \\
\hline
\end{tabular}
\end{tabular}




\begin{tabular}{|l|l|l|l|l|l|l|}
\hline & & $71.5)$ & & $36)$ & $89.8)$ & \\
\hline CRP & 6.9 & 75.8 & 39.3 & 26 & 85.2 & 12.5 \\
& & $(61.1$, & $(30.5$, & 17.3, & $(75.7,94$ & $(9.8,15.9)$ \\
& & $90.4)$ & $48.2)$ & $34.8)$ & $7)$ & \\
\hline
\end{tabular}

$6 \mathrm{mg} / \mathrm{dl}$ is helpful rather than total WBC of more than or equal to $15,000 .^{9}$

CRP concentration is dependent on the duration of fever suggesting that CRP is more reliable as an indicator of

Based on the ROC curve, cutoff point is fixed for each variable. For WBC the cutoff is 13.4 thousands per cu.mm. At this cutoff point sensitivity increased to $(81.8 \%)$. The cutoff point for ANC is 19.3 thousands per cu.mm. The sensitivity goes up by two and a half fold. Cutoff point for ESR is $17.1 \mathrm{~mm}$. The cutoffs for each variable, along with $\mathrm{p}$ value, Sensitivity, Specificity, PPV, NPV, Likelihood ratio.

\section{Discussion}

150 cases were included in the study. Out of 150 cases 96 cases were CRP positive, among them 25cases of SBI were identified. 9 cases were occult bacteremia (both CRP and blood culture positive). 4 cases of S.Pneumoniae, 4 cases of H.influenzae and 1 case of Klebsiella were isolated. 6 cases of urinary tract infection were identified (both CRP and urine culture positive) 1 case of klebsiella, 4 cases of E.coli, 1 case of H.influenzae were found in this study. 11 cases were diagnosed as pneumonia (both CRP and chest $\mathrm{x}$ ray positive). CRP has been evaluated as predictors of bacterial illness in febrile children. CRP was found to be having a sensitivity of $75.8 \%$, specificity of $39.3 \%$ PPV of $26 \%$, NPV of $85 \%$ and likelihood ratio of $12.5 \%$ in the present study.

The sensitivity of the present study correlates with Issacman and Pullium study but specificity is slightly higher than the Issacman study. Inpullium study only 77 children were included, the sample size was small. In Issacman study sample size is higher than the present study. Probably the sample size would have altered the sensitivity. The likelihood ratio is also increased when compared to other studies. CRP was found to be a useful screening test for occult bacterial infection. ${ }^{7}$

Receiver operating characteristic curves (ROC) for CRP, ESR.ANC, WBC were constructed. Based on the curve, cutoff values for each variable was determined that simultaneously maximizes the sensitivity and specificity. For each variable, patients were dichotomized into 2 groups based on the cutoff value and c2 analysis was done to assess the association between the dichotomized variables and the presence of SBI. For WBC cutoff fixed at 13.4 cells per cu.mm, which increases sensitivity from $60.6 \%$ to $81.8 \%$. ANC has a cutoff point fixed at 19.3 cells/cu.mm which increases sensitivity from $33.3 \%$ to $63.8 \%$. ESR has a cutoff point. ${ }^{8}$

Multilevel likelihood ratios and CRP concentration were calculated. A CRP concentration of $<5 \mathrm{mg} / \mathrm{d} 1$ had a likelihood ratio of SBI of 0.25 corresponding to a NPV of $94 \%$. A CRP concentration of $>15 \mathrm{mg} / \mathrm{di}$ had a likelihood ratio of SBI 14.6, corresponding to PPV of $80 \%$. Likelihood Ratios are a powerful clinical tool because a clinician may estimate the pretest probability of the presence of disease in a particular patients.

This study demonstrates CRP is both more sensitive and specific Indistinguishing children with occult serious bacterial infection from those without bacterial illness. Based on the curve CRP concentration of more than $4.5 \mathrm{mg} \%$ that maximizes the sensitivity. A CRP concentration more than bacterial infectionif fever has been present for more than 24 hours $^{10}$.However significant number of cases were also negative for CRP in this study.

predicting children with occult serious bacterial infection because when a febrile young child with no identifiable source of fever presents the clinician is faced with the dilemma for workup and antibiotic therapy.

The most useful test would predict children at risk of bacterial infection and therefore need workup and possible antibiotic therapy. Urinary tract infection remains common occult bacterial infection confirmed by culture and colony count. The results of urine culture are delayed by 24 to 48 hours. Similarly, the diagnosis of occult bacteremia by blood culture is delayed by a mean of 15 to 16 hours and up to 48 hours. Blood culture are positive in 3 to $5 \%$ of febrile young children with pneumonia. Children who received a chest radiograph, true prevalence remains unclear. More over it is very difficult to differentiate viral from bacterial pneumonias based on the chest radiograph alone.

CRP concentration measured from blood is a readily available inexpensive test. With recent availability of rapid CRP tests we can readily use in emergency settings. CRP may become valuable diagnostic tool in the initial evaluation of febrile young children for occult serious bacterial infection and determine which children need additional diagnostic tests and antibiotic therapy.

\section{Conclusion}

- Semiquantitative CRP is useful in predicting occult serious bacterial infection in children between $1-3$ yrs.

- CRP is considered to be better predictive test than total white blood cell count and absolute neutrophil count.

- $\quad$ CRP and ANC or CRP, ANC \&WBC combination is more useful than isolated CRP concentration.

\section{References}

1. In Nelson's textbook of paediatrics 18th Edn Robert M.Kleigman, Richard E.Behrman Hal B.Jenson, F.Stanton ; eds ,Elsvierpp 2004;pp 841-842.

2. Pullium $\mathrm{P}$, AttiaM ,Chronan $\mathrm{K} \mathrm{C}$ reactive protein in febrile children 1 to 36 months of age with clinically undetectable bacterial infection J. Paediatr2001;108:(1275-80).

3. Daniel J Issacman utility of serum $\mathrm{C}$ reactive protein for detection of occult serious bacterial infection, Arch pediatradolesc: med, 2002;(9) 905-909.

4. Lee GM, Harper MB.Risk of bacteremia for febrile young children in the post HaemophilusInfluenzae type B era. Arch PediatrAdolescMed 1998; 152:624-628.

5. SomanM.Charateristics and management of febrile young children seen in a university family practice. J Fam Pract.1985; 21:117-122.

6. Isaacman DJ, Shults J, Gross TK,et al. Predictors of bacteremia in febrile children 3-36 months of age. Peadiatrics2000; 106:977-982.

7. Kupperman N, Fleisher GR, Jaffe DM. predictors of occult bacteremia in young febrile children. Ann EmergMed.1998;31:679-687.

8. Shaw KN, Gorelick MG, McGowan KL, McDaniel Yakscoe M, Schwartz Js S. Prevalence of urinary tract infection in febrile young.

9. BachurR,PerryH,HarperM.Occult pneumonias: empiric chest radiographs in febrile children with leucocytosis. Ann Emerg Med 1999;33:166-173. 


\section{Years}

10. Teach SJ, Fleisher GR, Occult Bacteremia Study Group. Efficacy of an observation scale in detecting bacteremia in febrile children three to

Copyright: (C) the author(s), 2019. It is an open-access article distributed under the terms of the Creative Commons Attribution License (CC BY 4.0), which permits authors to retain ownership of the copyright for their content, and allow anyone to download, reuse, reprint, modify, distribute and/or copy the content as long as the original authors and source are cited.

How to cite this article: Mathew D, Mathew D. The Role of C Reactive Protein in Fever without Focus among Children Aged Between 1 - 3 Years. Acad. J Med. 2019;2(2):118-21.

DOI: dx.doi.org/10.21276/ajm.2019.2.2.29

Source of Support: Nil, Conflict of Interest: None declared. 